\title{
Motherhood and Survival in the Stalinist Gulag
}

\author{
Elaine MacKinnon
}

\begin{abstract}
This article analyzes the Gulag memoirs of four women political prisoners-Olga Adamova-Sliozberg, Liudmila Miklashevskaya, Nadezhda Joffe, and Valentina Grigorievna Ievleva-Pavlenko-to examine the interplay of motherhood and survival. Each was a mother of small children sentenced to forced labor camps in the northern polar regions of the Soviet Union. Motherhood played a complex role in their survival. The rupture in family relations, particularly the separation from their children, magnified the psychological and emotional stress of their incarceration. Yet, being a mother in the camps provided a compelling motivation to stay alive. It helped them to sustain a sense of normalcy by connecting them to their former lives and to the family unit that represented stability and sustenance amid the bleakness of their Gulag existence.
\end{abstract}

KEYwORDS: children, gender, Gulag, letters, motherhood, survival, terror

This article is the story of how four women experienced, perceived, and reflected on their experiences as mothers surviving in Stalin's Gulag. It considers their subjective sense of motherhood by interrogating their memories of how they coped in the camps, and how their identity as mothers shaped their lives as prisoners. It focuses directly on the complex relationship between motherhood and survival, and the impact of imprisonment on their ability to reunite with their children after leaving the camps. A consideration of the physical, emotional, and psychological trauma of mothers imprisoned in the Gulag illuminates an important dimension of the gendered experience of the Stalinist era's policies of repression, mass arrests, and the resulting disruption of familial and communal ties. The four women and their memoirs are: Olga AdamovaSliozberg, My Journey; Liudmila Miklashevskaia, Povtorenie proidennogo (Reliving the past); Nadezhda Joffe, Back in Time: My Life, My Fate, My Epoch; and Valentina Grigorievna Ievleva-Pavlenko, Unedited Life. ${ }^{1}$ Through their unique personal accounts we can find compelling insights into the common experiences of Gulag mothers and the impact of their imprisonment on their families. 
Motherhood empowered yet complicated the survival of these four Gulag mothers. As mothers, they had to worry about more than just their own survival. In addition to enduring the same harsh conditions as other prisoners, they faced the psychological and emotional stress of separation from their children and feelings of utter helplessness with regard to their welfare. Even when they survived, they faced serious and sometimes irreparable ruptures in family relations, and in some cases they were the only ones able to repair the torn fabric of their lives. With these four women, their children's fathers did not survive the camp or were not present at their release. Yet, being a mother in the camps provided a strong moral, emotional, and physical motivation to stay alive. It gave these women a sense of normalcy and connectivity to their former lives and to the familial bond that the state sought to destroy; their maternal role proved a solid foundation they clung to amid the turmoil of their broken personal and professional lives.

Understanding survival strategies is central to Gulag studies. ${ }^{2}$ The struggle to endure the extreme physical conditions while also coping with the loss of family, friends, profession, along with all semblance of normal life is a compelling story. Official Soviet death rates for the camps range from 1 to 6 percent, with the peak reached during the war years, and a total of approximately 1.6 million. But Gulag statistics are unreliable, and besides underreporting deaths, do not include those prisoners who died during interrogation, transport, or within days or weeks of being released. ${ }^{3}$ Survival depended upon a series of complex factors, including age, state of health, where and when one was arrested and sentenced to the camps, which camps one ended up in, vocational skills, and often, pure luck.

This article asserts that gender is an additional factor that must be considered, and motherhood is a unique aspect of a woman's gendered identity that affected the capacity to survive. Motherhood was embedded not simply in a biologically determined feature of a woman's consciousness, but also as a cultural, social, and political construct, particularly in Soviet Russia, where patriarchal attitudes remained strong, despite major gains by women after 1917.4 The revolution brought women political equality, and as part of the Stalinist industrialization drive they entered previously male-dominated professions such as law, engineering, and construction. By 1937, the number of women in higher education had grown to 43 percent. ${ }^{5}$ But the goal of Bolshevik feminists such as Alexandra Kollontai for emancipating women from the kitchen and nursery went unfulfilled. ${ }^{6}$ Beginning in the 1930s, the Stalinist state instituted pro-natalist policies that reasserted maternity as a sacred duty of Soviet women, rewarded women who bore more than six children, imposed taxes on those between the ages of twenty and forty-five who were childless, and criminalized abortion. The ideal as well as the state duty for the "new" Soviet woman was to become a mother. ${ }^{7}$ This conservative turn in family policy did not mean women left the workforce, only that women were expected to combine careers with having children. ${ }^{8}$ Women in the Soviet intelligentsia, a category encompassing all four of these memoirists, enjoyed their status as professionals and often employed peasant nannies to help in the home, but managing their children's needs remained their responsibility within the household. Thus, for a woman who was a mother, imprisonment threatened a core identity as well as a sense of duty fully affirmed in official propaganda. ${ }^{9}$ As Veronika Shapovalova points out, motherhood 
made the camps more traumatizing for women because imprisonment blocked their ability to live up to deeply ingrained cultural expectations that they should be ideal mothers, sacrificing all to take care of their children and provide for their needs. Any digression from this ideal compounded the emotional distress and despair already felt by those uprooted from their normal lives and from their loved ones. ${ }^{10}$ But it also infused them with a strong moral and emotional imperative to survive for their children, especially when the Stalinist terror claimed spouses and other family members.

This article contributes to the growing scholarship on women in the Gulag. Golfo Alexopoulos has illuminated the myriad ways in which women were affected by Stalinist penal policies. She has shown how, because of the tendencies of the Stalinist regime to view crime in collective terms, as "family networks," women as wives, mothers, and sisters became terror victims purely on the basis of kinship connections. ${ }^{11}$ Alexopoulos has also traced the periodic amnesties and releases for pregnant women and women with families in the Gulag that followed in the wake of the demographic devastation of World War II and provided at least some degree of recognition that high rates of incarceration were damaging the nation's social fabric. ${ }^{12}$

Wilson T. Bell has explored issues of gender, sexuality, and power in the Gulag. In his article "Sex, Pregnancy, and Power in the Late Stalinist Gulag," Bell focuses on the complexities of love, sex, and heterosexual relationships in the camps, which flourished despite mandated segregation of male and female prisoners and regulations against such behaviors. According to Bell, sexuality in the camps was "part of the negotiated power of the camp system," that in some cases became for prisoners a source of resistance and autonomy. The regime's laxity in enforcing sexual segregation, he argues, is revealed in the fact that Soviet camps did provide maternity wards and children's nurseries for women, which he roots partially in the Stalinist state's pro-natalist ideology. ${ }^{13}$ Understandings of the gendered experience of the camps has also been enriched by the continued publication of memoir literature, oral interviews, and anthologies of personal recollections and letters. ${ }^{14}$

Motherhood as an important dimension of a woman's experience of the camps has over time attracted increasing attention from scholars. Alexander Solzhenitsyn discussed it in his classic work The Gulag Archipelago, though only as a small section of his one chapter on women. He described conditions endured by the mamki, camp slang for the women who became pregnant in the camps and gave birth there. ${ }^{15}$ Anne Applebaum in her 2001 Pulitzer Prize-winning book also elaborated on the challenges facing mothers in the camps in her chapter on women and children. ${ }^{16}$ Emma Mason's 2001 contribution to the volume Women in the Stalin Era, "Women in the Gulag in the 1930s," likewise included a small section on mothers in the camps. ${ }^{17}$ The volume "Dorogaia Ekaterina Pavlovna ..." ["Dear Ekaterina Pavlovna ..."], which includes letters written to E. P. Peshkova, who headed organizations set up to aid political prisoners, first the Moscow Political Red Cross (1918-1922) and then Ekaterina Peshkova's Aid to Political Prisoners (1922-1938), broadly illuminates how policies of the first two decades of Soviet power affected women and particularly women with children; many of the letters are from women pleading for assistance due to their inability to find work and feed their children as a result of their husband's or their own arrest or exile. ${ }^{18}$ Cathy Frierson and Simeon Vilensky's Children of the Gulag recounts mothers' experiences in 
the camps and contains archival reports and sources related to their situation, though the main focus is on what children endured. The documents included shed light on the status and treatment of mothers and children in the camps, and conditions in camp nurseries and orphanages. ${ }^{19}$ A number of publications in Russia and Ukraine by O. I. Chesnokova, Oksana Kis', Vadim Gritsenko, and Tamara Vronskaia have explored women's gendered experiences in the camps, including motherhood and pregnancy. ${ }^{20}$ Veronika Shapovalova and Liubov' Anatol'evna Maksimova have examined multiple aspects of what it meant to be a mother in the camps. Each discusses the trauma felt by arrested mothers forced to leave children behind as well as the circumstances in which women in the camps became pregnant, including as a result of rape and coerced cohabitation with camp bosses or guards, a pragmatic desire to receive higher rations allotted for pregnant prisoners, and for some, a longing for normalcy and a desire to feel human again by giving life to another. ${ }^{21}$

Building on this growing body of literature, this article uses memoirs as a means to explore the personal experience of being a mother in the camps and women's own subjective sense of their maternity not only in the context of imprisonment but in their post-Gulag reconstructions of their camp lives. Recent works have sought a more personalized focus on individual prisoners, such as Orlando Figes's Just Send Me Word: A True Story of Love and Survival in the Gulag. Figes traces the life of a single prisoner in the Gulag to show the role that personal relationships and communication played in survival, not only among prisoners themselves but between prisoners and loved ones living "outside the zone," and prisoners and free personnel. Such an approach reveals the larger patterns of life and survival in the Gulag and beyond, but also personalizes the tragedy. ${ }^{22}$ This article likewise explores the camp experiences of these four women to affirm the importance of familial relationships to a prisoner's survival through the lens of a mother's relationship with her children, severed by the Stalinist terror but kept alive until release from the Gulag brought the opportunity to restore it. The frame of analysis is each woman's subjective sense of motherhood, based on her own interior voice as expressed in her memoir. It considers how each understood her identity and role as a mother, and how this in turn informed her actions as a prisoner.

Memoirs are indeed an important avenue into the personal dimensions of the camp experience not to be found in official reports or documents. The insights as well as the caveats in using memoirs as historical sources have been insightfully illuminated by the work of Leona Toker and Dairus Tolczyk on Gulag narratives. ${ }^{23}$ Jehanne M. Gheith and Katherine R. Jolluck point out in their introduction to a collection of oral histories from the Gulag that some scholars have raised questions about the reliability of memoirs due to the proliferation of personal writings that have come out since the late 1980s and the possibility that a survivor may be incorporating their experiences into a collective memory of repression, following set patterns or tropes created by the vast number of widely read survivor narratives. Therefore it is necessary to read such texts carefully and try to distinguish between unique personal experiences and what may be rooted in collective memory, and consider the erosive impact of time on memory. ${ }^{24}$ I argue that experiences involving emotional trauma, especially with regard to children, are more likely to remain vivid in a person's consciousness, thus strengthening the credibility of memories associated with motherhood and relations with children in 
and out of the camps. In each of these texts the memories associated with motherhood also have unique elements that enhance their reliability and value as sources of insight into what it was like to be a mother in the Gulag. Even if maternity is only one element of their remembered experience, their recollections and their perception of what this meant for them gives us insight into what were common experiences for countless numbers of women who either did not survive or who never wrote down what happened to them. That these women did offers invaluable insight into one of the most wrenching dimensions of the personal toll of Stalinism - the tearing apart of families for inexplicable and unsubstantiated political campaigns of terror. Their memoirs are eyewitness testimony and as such a form of protest against what was done to them and to others. ${ }^{25}$ As Irina Paperno has pointed out, the writing of memoirs can be considered an effort to turn private lives into "public texts"; they become a form of social therapy, and a way to fill a vacant space in one's soul. They help us to measure the impact the Gulag had on women who were mothers. ${ }^{26}$

\section{Background: Women in the Gulag}

Before turning to the stories of the four Gulag mothers, it is important to contextualize their situation in the broader experiences of women in the camps. Women were a minority among Gulag prisoners, both criminal and political, almost from the very beginning; they were generally not specifically targeted, with the exception of prostitutes, who were arrested in periodic urban campaigns and sent to some of the first camps and colonies set up specifically for women. ${ }^{27}$ Yet every wave of mass arrests from 1929 to 1953 included women, particularly those who worked in prominent positions in the Bolshevik Party, in state economic ministries, in universities and research academies, in industry, and in the world of the arts. According to Barbara Clements, women made up 11 percent of all those prosecuted in the late 1930s by the Soviet legal system. ${ }^{28}$ The Soviet system proclaimed women to be equal to men in political and social status, and had encouraged women to enter the workforce and pursue traditionally male occupations. Consequently, professional prominence made them more vulnerable to the Stalinist terror. Even more women fell victim to the increasing criminalization of such transgressions as being late to work or having to leave early. ${ }^{29}$ There were many foreign women as well in the camps, including Poles, Germans, Chinese, Iranians, Romanians, and Finns, arrested as part of a Stalinist effort to remove any potential "fifth column" from the country both before and during World War II. Women also made up a large proportion of those arrested throughout the Stalinist period for religious beliefs and practices. Furthermore, in 1937 and 1938 anyone who had ever been arrested before, such as kulaks, aristocrats, believers, or non-Bolshevik socialists, was also rounded up, and this included women.

Among the most gendered category of terror victims were the zheny izmennikov rodiny (wives of traitors to the Motherland), who were arrested because they were family members of men accused and convicted as "traitors," as if their roles as wives and mothers subsumed male guilt. Although during the Great Terror of 1937-1938, far fewer women than men were executed, the regime clearly feared that the wives, moth- 
ers, and daughters of those arrested could not be trusted and had to be isolated, first in special camps for wives and family members, and later in regular Gulag camps and prisons. The largest of the women's camps was in Kazakhstan, the Akmolinskii Lager' Zhën Izmennikov Rodiny (Akmola Camp for the Wives of Traitors to the Motherland, known by its Russian acronym ALZhIR), which operated from 1937 to 1953, and held over eighteen thousand women of sixty-two different nationalities, and not just wives, but also mothers, sisters, and daughters of "enemies." Two other such camps existed in Mordovia and Tomsk. ${ }^{30}$ The 1937 operational order of the Soviet secret police, the Narodny Kommissariat Vnutrennikh Del (People's Commissariat for Internal Affairs, henceforth abbreviated as NKVD) decreed that wives of arrested "traitors to the Motherland, members of right-Trotskyite espionage-diversionary organizations, convicted by the Military Collegium and military tribunals" were subject to exile or "punitive measures," meaning camp terms of five to eight years. Wives living in major cities were particularly targeted for fear that their "contagion" could spread too easily. Women could be arrested for not having denounced their husbands, and this applied to divorced wives as well. The orders also decreed that children of enemies were to be put into state-run children's homes. ${ }^{31}$

During the 1930s, women were generally less than 10 percent of the Gulag population, but this number increased during World War II and did not dip below 20 percent until 1955. Women were only 8.1 percent of the prisoners in 1940, but by January of 1945 , according to some estimates, they were as high as 30.6 percent. ${ }^{32}$ A major reason for the increase in female prisoners were the harsh labor laws enacted for wartime, which did not take into account the fact that women with children often had to miss or be late to work due to a lack of childcare options. ${ }^{33}$ After the war, the percentage of women in the camps dropped to 22 percent in 1948, and then to 17 percent during 1952. ${ }^{34}$ Of these women in the camps, though, it is not known precisely how many of them were mothers when they were arrested.

Motherhood provided a complicated, often ambiguous array of challenges and possibilities for women in the camps. As stated earlier, women who were mothers had a compelling reason to survive-their children needed them. Yet being a prisonermother could be intensely stressful, and for some women the psychological trauma of separation was more debilitating than empowering. For those who did not know what had happened to their children after their arrest, because usually children who were not nursing did not accompany their mothers into the camps, the anxiety could be overwhelming. These women could thereby be vulnerable to the manipulations of interrogators, who threatened to put their children into orphanages if they did not sign confessions or denounce others. It could be equally unsettling for women whose nursing infants were allowed to stay with them (in part as a product of the official emphasis upon breastfeeding in the 1930s), because of their exposure to the harsh conditions of prison and transit. When this in many cases proved deadly for infants, it created further sources of guilt and torment for the mothers. ${ }^{35}$

For mothers in the camps who were separated from their children, having the right to correspondence and being able to stay connected to one's children was crucial. Mothers often used letters to share advice and interests and to stay involved in their children's lives; letters embodied the vital family bonds that provided emotional 
support and a connection to her former life. Nina Vsevsiatskaia wrote books and stories for her children that she sent to them in lieu of being able to tell them bedtime tales each night. Yet it could be devastating for these women if these connections were severed or if the children did not or could not continue to correspond. ${ }^{36}$ The forced separation, grief, and fear could drive one to distraction, depression, and suicide. Liudmilla Granovskaia describes how her camp of wives of enemies forced the administration to allow them to correspond with their families, but then ten women became disconsolate to the point of desperation when they started to receive letters. She refers to "endless suicide attempts" by women over the loss of family. ${ }^{37}$

Becoming a mother while in the camps was another dimension of the maternal Gulag experience. Unlike the Nazi camps, the Soviet Gulag did make accommodations for women who gave birth in the camps. ${ }^{38}$ Regulatory codes set aside special sections inside prisons and camps for nurseries to accommodate babies born up until the age of eighteen months to two years. In the postwar period there were over two hundred infant nurseries, though in some camps they just sectioned off parts of general barracks for infants and children. ${ }^{39}$ Women who became pregnant were generally allowed to have the baby. However, there were cases where camp authorities forced women to have abortions, despite the fact that they were illegal; sometimes women themselves attempted to abort the pregnancy. ${ }^{40}$

In the postwar period, increases in the numbers of pregnancies and of children in the camps triggered concern among camp administrators over mounting costs of caring for infants and children. ${ }^{41}$ In 1941, 8,500 pregnant women were reportedly in the camps and prisons; the number dropped to 4,588 in 1948 but then rose sharply to 9,100 as of 1 March 1949. A similar rise occurred in the number of women prisoners with children-in 1948, there were 10,217 women prisoners with children, and by 1949, the number had grown to 26,150, making up 6.3 percent of the general number of female prisoners in camps and colonies. ${ }^{42}$ By 1953, the Main Administration of Forestry Camps alone was managing thirteen children's homes with 3,569 children under two years of age. ${ }^{43}$ It is difficult, though, to determine the total number of women who were pregnant in the camps without knowing how many women were forced to have an abortion or who had miscarriages, a figure not yet found in the statistical record. ${ }^{44}$ This rise in the numbers of women who were pregnant or had small children was one of the factors that pushed the state to amnesty nonpolitical female prisoners with children. ${ }^{45}$ In 1947, over five thousand pregnant women and 12,702 women with children were released early. ${ }^{46}$

At the same time, these amnesties provided incentive for women to continue to become pregnant. Many pregnancies, though, were due to female prisoners being raped by guards and criminal prisoners, or being forced into cohabitation by those with power over their circumstances in the camps. ${ }^{47}$ Nonetheless, as Solzhenitsyn and others have shown, love did exist in the camps, and there were camp "marriages," though many were purely practical in nature, with women seeking male protectors. According to Bell, sexuality also served as a means for defying the system and the dehumanization of imprisonment. ${ }^{48}$ Shapovalova suggests as well that women sought pregnancy as a way of gaining control over their lives. ${ }^{49}$

Pregnant women were granted special accommodations that could be life enhancing, and may have induced some to become pregnant deliberately. ${ }^{50}$ They received 
increased rations during pregnancy and nursing of bread, animal fats, vegetables, potatoes, and sugar (when available), and were released from night work and heavy manual labor during the last two months of pregnancy and for up to two months afterward. Only pregnant women received daily rations of milk. ${ }^{51}$ Nursing mothers (usually for six to nine months) could be assigned to work within the camp zone to be closer to their infants, though not in every case. Pregnant women could buy more produce from the camp commissary and were allowed scheduled exercise periods. ${ }^{52}$ Hilda Vitzthum recalls how a disoriented peasant woman was able to become better acclimated to the camp during the time that she was off heavy labor while pregnant and nursing. ${ }^{53}$

Having a baby could give one a reason to live; in the words of L. A. Maksimova, it offered for some a "second wind," reviving hope of being able to achieve some degree of normalcy or to find personal fulfillment. ${ }^{54}$ Yet it could also be physically dangerous. Prison women received inadequate prenatal care, limited sanitation and medical supplies, plus the allotted rations more often than not were less than what was officially prescribed. ${ }^{55}$ After giving birth, they faced having to give the baby over to camp nurseries with strictly prescribed access. Regulations allowed nursing women to see their babies only at the set feeding times, beginning with seven daily but gradually reduced thereafter. ${ }^{56}$ Women who were not nursing had less access to their babies, as did even nursing women once they stopped breastfeeding, which often occurred after only two to three months due to poor nutrition. The conditions in such facilities and in camp nurseries were often quite poor, though there were some that had high standards of cleanliness and care. ${ }^{57}$ Many memoirs describe extremely primitive facilities that produced high rates of infant and child mortality. Those children who did survive to the age of two (or three or four depending on the camp) had to go into underfunded, overcrowded state orphanages, staffed by untrained and often corrupt personnel. Mothers lived in fear of having their children taken away to these homes, for many never saw them again, or when they were reunited, the children had severe developmental, health, or emotional problems. With little access to medicines, undernourished and poorly dressed children living in the camps and in state orphanages connected to camps suffered especially from such afflictions as scarlet fever, measles, dysentery, and pneumonia. ${ }^{58}$ So, having a child in these circumstances could produce extreme anxiety and heartache if the child did not survive..$^{59}$ Hava Volovich, who said she sought to have a baby as a way of fulfilling an emotional need for love, suffered the trauma of losing her daughter to the poor conditions of infant care in the camp nursery. She described horrific scenes of babies being force-fed, kicked, and shoved by rough, indifferent nurses. According to her, three hundred babies died each year in her particular camp nursery. ${ }^{60}$

\section{Motherhood in the Camps: Four Gulag Stories}

Olga Adamova-Sliozberg, Liudmila Miklashevskaia, Nadezhda Joffe, and Valentina Grigorievna Ievleva-Pavlenko and their memoirs were chosen for particular commonalities and differences that illuminate key dimensions of motherhood in the Gulag 
camps. All four were mothers when arrested; one also gave birth while in the camps, thus giving us insight into what it was like for a woman prisoner to become pregnant, give birth, and try to care for an infant while enduring the hardships of incarceration. Nadezhda Joffe had two daughters, Natasha and Kira, who spent most of Nadezhda's internment with her mother and later her uncle. At the time of her arrest, one of her daughters was very ill, and she successfully demanded from her interrogator the right to talk with the physician treating the child. Nadezhda gave birth to a third child, Lera, early in her camp term, after a brief period of cohabitation with her husband, and she had this child with her throughout her first period of imprisonment. Liudmila Miklashevskaia had one daughter, Elena, who was seven years old when Liudmila was sent into exile in 1937. Upon her arrest, Liudmila sent Elena to her sister-in-law, Maria Lazarevna Tronskii, in Leningrad, who raised her as her own daughter throughout the time of Liudmila's imprisonment. Olga Adamova-Sliozberg's children were Alexander, aged six, and Elga, aged four, and her parents acted courageously to save the children from a state orphanage. Throughout Olga's incarceration, her children lived with family and enjoyed relatively stable childhoods in spite of their mother's fate. Valentina Ievleva-Pavlenko gave birth to a daughter, Bella, in 1945, but her mother cared for the child while Valentina attended school. Valentina's mother continued to do so after Valentina's arrest, when Bella was eighteen months old. Valentina's mother died soon thereafter, however, and Bella went into an orphanage until Valentina's release.

These four women shared a similar socioeconomic status as part of the educated Soviet intelligentsia or administrative elite. Nadezhda was the most prominent, the daughter of Jewish-born Adolf A. Joffe, a high-ranking Bolshevik foreign affairs official close to Trotsky. Born in 1906, Nadezhda inherited her father's passion for politics. She followed him into the Left Opposition, for which she was arrested in 1929 and exiled for three years. A trained economist who worked for the State Bank, Nadezhda was unique among these four women prisoners in that she was not targeted as either a wife or daughter of an enemy but for her own oppositionist activities. She was arrested in April 1936, ten days before her husband, Pavel, a regional party official. Liudmila Miklashevskaia was born in Odessa in 1899 to a middle-class Jewish family. Her first husband was the actor and playwright Konstantin Miklashevsky. The pair moved to Paris in 1924, but soon divorced, and Liudmila returned alone three years later to the USSR. She was exiled to the Arkhangelsk region in 1937 as the "wife" of a "traitor to the Motherland" after the arrest of her second husband, historian Isaak (Izia) Trotsky. She and her daughter were sent to a remote, isolated village, Semenovskoe, where she found work as a typist, but then in May 1938, Liudmila was arrested, initially for the charge of not having informed on her "counterrevolutionary" husband. Later the case against her came to include accusations of anti-Soviet agitation and allegedly conspiring to kill Nikolai Yezhov, Stalin's head of the secret police (NKVD) from 1936 to 1938. She was sentenced by the Military Collegium of the Supreme Court to a ten-year term under Article 58, sections 8-17, as a "terrorist."

Olga Adamova-Sliozberg was born in 1902 in Samara and grew up in a middleclass Jewish family. She trained as an economist in Moscow, and enjoyed a life of privilege with her husband, Yudel Ruvimovich Zakgeim, a professor at Moscow State University. She was arrested in the spring of 1936, following her husband's arrest as 
a Trotskyist. Like Liudmila, she was tried by the Military Collegium of the Supreme Court and convicted of having joined a terrorist group to kill the high-ranking Communist Party leader and head of Soviet industry Lazar Kaganovich, and likewise was sentenced under Article 58, sections 8-17.

Valentina Ievleva-Pavlenko was the youngest when arrested. Born in 1928, she was the daughter of a man who held high administrative positions in Arkhangelsk until his arrest and execution in 1937. Her mother was a housewife but after her husband's death she worked in a hospital as a nurse's aide. Valentina was a correspondence student at the Moscow Institute of Foreign Languages when arrested in 1946; she was initially accused of espionage, but was eventually sentenced to a six-year term for anti-Soviet propaganda. Her status as a daughter of an enemy probably contributed to her arrest, but she had also socialized freely with American military personnel during the war and implies in her memoir that she was the victim of malicious gossip. ${ }^{61} \mathrm{Na}-$ dezhda, Liudmila, and Olga were married at the time of their arrest, and in each case their husbands died or were executed within two years of their arrest. Valentina had what she refers to as a common-law husband, but they were not together when she was arrested, and his fate is unknown. ${ }^{62}$

These four women are not representative of the entire female population of the Gulag, but rather are examples of women who were arrested as "political prisoners" under Stalin, and as such were incarcerated on false charges of conspiracy and antiSoviet agitation. Between 1929 and 1953, such prisoners made up approximately onefourth to one-third of the forced labor camp population; this classification applied to those who were arrested for alleged "counterrevolutionary crimes" as defined by multiple points of Article 58 in the Russian Soviet Federative Socialist Republic (RSFSR) Criminal Code. ${ }^{63}$ Thus they shared a similar psychological and emotional framework as prisoner mothers - as victims of political terror, they had to grapple with being unjustly targeted by the state, trapped by forces they could not control, while also having to worry about the fate of their children. Nadezhda alone understood why she had been arrested, because she was a known Left Oppositionist, though she had not committed any act to justify her incarceration. Three of the four women were also Jewish; although none seem from their memoirs to have practiced Judaism as a faith, they articulate a consciousness of Jewish identity that in some cases may have influenced relationships formed in the camps and provided social support aiding in survival.

These women were chosen as well because each were sent far from their homes and families to similar types of camps in the northern polar regions of the Soviet Union. Olga and Nadezhda labored in the notoriously harsh region of Kolyma in the far northeastern portion of Siberia, part of the Magadan camp system, near the Arctic Circle. Valentina spent her camp years in north-central Siberia in what was known as Camp 501, which built the Labytnagi-Salekhard Railroad. Liudmila Miklashevskaia served her term in Viatlag in the Viatka region, Kirov Oblast, one thousand kilometers northeast of Moscow. Nadezhda, Olga, and Liudmila were arrested during the period 1936 to 1938, and Valentina in 1946. Liudmila served the longest term, ten years; Olga received eight years, Valentina, six years, and Nadezhda, five. Olga, Liudmila, and Nadezhda were all rearrested in 1949 and sentenced to terms in exile, which lasted until the death of Stalin. 
These particular memoirs were also chosen for reasons that make them viable and valuable sources for studying diverse facets of motherhood in the camps. Olga Adamova's memoir is one of the most well-known and well-read of Gulag narratives; it was one of the earliest to appear in samizdat (meaning self-publishing: the underground reproduction and distribution of manuscripts banned by the Soviet censors) circulation. She started writing it soon after leaving the camps and thus it stands more as a foundational account of the Gulag rather than one that may have elements incorporated from collective memories. Nadezhda Joffe's work offers the perspective of a woman who gave birth in the camps but is also unique because it was written by a Left Oppositionist. It is very political in tone, which makes the references to maternity a compelling example of how public and private concerns could coexist in prisoners' lives and memories. Liudmila Miklashevskaia's memoir is compelling as an insight into her personal, individual experience of the camps because she states directly that she is only including moments that were particularly meaningful and distinct for her, rather than regurgitating details already revealed by other memoirists. Valentina Ievleva-Pavlenko's account bears as well features that are very individual and unique, especially her frank and open depictions of her sexuality in the camps and liaisons with both criminal prisoners and administrators in her determination to survive.

Additionally, with the exception of Olga Adamova's narrative, which circulated in samizdat, the memoirs were not published until many years after the authors were released from the camps, thus making them similarly subject to the eroding impact of time on memory. Three of the women began writing their memoirs at a similar juncture in their lives, when they were approximately in their sixties or older. Nadezhda Joffe began writing her memoirs in 1971-1972 for her children and grandchildren, but did not publish them until the early 1990s.$^{64}$ Of the four memoirists, Olga Adamova was the youngest when she began writing her narrative; she began it immediately after being released in 1946 from her first term in the Gulag. Upon her second arrest, she buried her manuscript in the garden at the family dacha. But after returning from exile, she was not able to recover this first draft of her memoir, and she had to rewrite from memory, completing the manuscript in 1964. Although distributed through samizdat, My Journey was not published in Russia until 2002 by Simeon Vilensky's Vozvrashchenie Press, when it was expanded by the author to include additional chapters on her family ${ }^{65}$ Liudmila Miklashevskaia did not begin writing her memoir until the last year of her life (1976) when, at the age of seventy-seven, she developed a crippling eye disease. Her memoir is similar to Joffe's in that it encompasses her entire life, not just her time in the camps. It was not published in Russia, however, until 2007, when it appeared in the volume Chemu svidelteli my byli: Zhenskie sud'by XX vek (What we witnessed: Women's fate in the 20th century). Ievleva-Pavlenko's narrative was not originally written for publication, but was solicited to be part of the archive of the St. Petersburg branch of Memorial. ${ }^{66}$ It appeared in English in 2001 in the collection Remembering the Darkness: Women in Soviet Prisons. ${ }^{67}$

These memoirs also illustrate differing ways in which motherhood figures in the memories of survivor-mothers; for some women, such as Liudmila Miklashevskaia, her memory attributes her survival solely to her determination to return to her daughter. Most of what she describes about the camps relates to her experience as a mother. 
For Valentina, on the other hand, motherhood is far less prominent in her account, and she attributes her survival to her own personal and sexual attributes, thereby reminding us that motherhood was only one facet of a woman's gendered experience of the camps. Likewise, both Nadezhda and Olga write not only as mothers but also as daughters, and more so than either Liudmila or Valentina, each chronicles the larger injustices of the Gulag. Nadezhda dedicated the first part of her memoir to the life and legacy of her father, A. A. Joffe; the first eight chapters are about his life, and his fate (he committed suicide in 1927 in protest against Leon Trotsky's expulsion from the Communist Party). She peppers her narrative with sharp critiques of Stalinism and its corruption of Bolshevism and describes prisoners who were interesting to her politically, particularly fellow Oppositionists or Old Bolsheviks whose so-called crimes reveal the tragic absurdity of the Stalinist terror. Olga uses her memoir to pay tribute to her mother's courage in taking care of her children after her arrest and in fighting to get Olga acquitted of a terrorist charge, which enabled her to be released on time in 1946. ${ }^{6}$ Olga emphasizes that while she was in the camps, she worried over her mother's health, but she also derived spiritual strength, comfort, and even sanctuary from her thoughts about her mother. ${ }^{69}$ The memoir documents the breakdown of her faith in the Soviet system and its leaders, and provides a keen, almost journalistic account of the absurd charges brought against innocent persons, the cruel and malicious treatment of prisoners, and the destruction of family and careers. But even if the prominence of the maternal theme in the narrative differs, each memoirist makes clear that her identity and role as a mother affected her life in the camps, and the way each refracts her experiences as a mother offers needed and valuable insight.

\section{The Ambiguities of Motherhood and Survival}

It should be noted that beyond being mothers, each had other factors increasing their chances for survival. All four women were arrested at a young age, and each was sentenced to ten or less years. In her memoir, Nadezhda strongly emphasizes that she benefited from having been arrested in 1936 rather than 1937, when many Left Oppositionists would either be shot outright or sentenced to much longer terms. ${ }^{70} \mathrm{Ad}-$ ditionally, all four managed to have intermittent breaks from manual labor, assigned to lighter work in offices or in the barracks, or received periods of rest in hospitals. Nadezhda and Valentina performed in plays and musical productions, which afforded them a creative outlet and access to better rations. Liudmila's determination to survive led her to convince a doctor in 1940 that, despite a lack of any medical training, she could learn to be a nurse. During the war, she was assigned to a medical clinic for free personnel "outside the zone," and was able to have her daughter visit her there. Physical survival was indeed the product of intersecting factors and circumstances, but motherhood was key for spiritual and emotional resilience; it gave each the will and purpose for engaging in survival strategies.

Certainly all four of these women affirm that they felt a moral and emotional imperative to survive for their children. But they also make it clear that being mothers brought them added anxiety that haunted them throughout their imprisonment. 
They were physically separated from children still young enough to be dependent upon them for nurturing, and could never simply focus on their own individual survival. They had to cope with the loss of control over their children's well-being and a frightening estrangement from all semblance of normalcy in familial relations. As Olga writes: "In prison I slept badly. Exhausted during the day, I would fall asleep around midnight and almost always saw the children in my dreams. I played with them. I kissed their feet, their little necks and heads . . . At four o'clock I would wake up as if from stabbing pain in my heart-yes, they have taken my children from me and maybe I would never see them again!"71

Nadezhda, Olga, and Liudmila each describe efforts on the part of investigators and interrogators to manipulate them by claiming they had arrested or questioned their children, or suggesting that harm could come if compliance did not follow. Each fought to think through the claim rationally and fortify themselves against such tricks. Liudmila was fortunate in that her courageous landlady had appeared and let her know through the prison windows that someone had come and taken Elena to her sister-in-law in Leningrad. ${ }^{72}$ It was particularly hard for Olga because she received no news of her children during the first year of her incarceration, and so had no way of knowing whether or not the interrogators' threats of putting them into a children's home were true or not. She was able to put her fears to rest when she finally received a letter from her mother telling her they were safe. ${ }^{73}$

Once in the camps, the pain of their separation from their children was compounded by the fact that speaking about it often became a taboo subject. Denial and distance were everyday tactics for dealing with anxiety both for individual comfort and to avoid disturbing fellow prisoners. Olga notes in her memoir that in prison, to avoid hysteria, the women agreed to not talk about their children. She describes in one passage what happened when a pregnant woman was brought into her cell and then went into labor; this prompted one woman into hysterics over the fate of her crippled son, which then agitated everyone and led to much wailing and suffering. Because of this, "Only during the sleepless hours of the night, from four (in our cell you could hear the striking of the clock) until six (wake-up time) I allowed myself to remember the children." ${ }^{74}$ A similar pact of silence prevailed among Nadezhda's circle of friends in her first camp in Magadan. ${ }^{75}$ Nadezhda, Olga, and Liudmila each suffered chronic insomnia, and describe endless nights lying awake, thinking in silence about their children, their broken families, and rereading over and over any form of correspondence they had. In 1939, Nadezhda ended up in a hospital after suffering a seizure brought on in part by the news that her mother, who had been keeping her two oldest daughters with her, had been arrested. Fortunately, her daughters had been able to get to their great-grandmother's house and were staying there, but Nadezhda was tormented with thoughts of her children suffering endless emotional trauma from the continued arrests of those whom they loved and trusted. ${ }^{76}$

Despite such strains, motherhood made each feel she had little choice but to survive. Nadezhda includes in her memoir a dying woman's comment when she learned that Nadezhda had given birth while a prisoner, and now had an infant to care for in the camps. With pity in her eyes, the woman said to Nadezhda, "Yes, that's too bad. You can't even die. What can be done? Go on living." 77 Among these memoirists, it 
is Liudmila who is the most adamant that it was motherhood alone that enabled her survival. As she describes it, all that mattered to her was being able to see her daughter again. On the night of her arrest, as she prepared to go with the officers, Elena had wondered how she could live without her mother, and Liudmila had promised her that she would return. Her plaintive words haunted Liudmila, and her soothing reassurances to Elena thereupon became her covenant. Everything Liudmila did in the camp was aimed at enabling her to fulfill this pledge:

I went up to my daughter, who was shaking all over. I held her in my arms and told her that this was all a mistake, that we were good people, that I could not have done anything that was bad, and that I would probably be returning home soon. "Oh mommy, papa did not do anything bad but he hasn't come back yet! . ." Her words sent a chill through me. These midnight visitors had aged my child by at least five years . . . But then she looked at me again and began to sob as she cried out, "What will I do without you, mommy?" "Please do not cry - you must be brave for me. This is so hard for me. Think how I will feel to be away from you! I give you my word that I will return. I do not know exactly when that will be, but I will return and we will be together again." 78

The fact that she was a mother also aided Liudmila's survival in a very practical sense. She benefited from the packages that her daughter was able to send to her with extra food rations, fats, sweet treats, and luxuries; Elena could do this because her aunt and uncle were well off with connections in Leningrad and abroad.

The letters these women received from their children acquired a meaning beyond mere correspondence; they served as an inspiring life force of their own. For Liudmila, they were more precious to her than bread, and she kept them close to her twenty-four hours a day. She could not contemplate the next day without the physical closeness of the one item she knew her daughter had touched. Elena's letters enabled her to visualize her daughter going through her daily routine, and just being able to physically touch the signature at the bottom of the page revitalized her. The letters came to embody the very person of Elena for Liudmila, and only they could soothe her despair over the unjust hand she had been dealt. ${ }^{79}$ For Olga, letters too were a physical link. She could kiss her son's letters and feel as if she were witnessing their growing up through tracing the subtle changes in their handwriting skills: "I am a happy woman. I receive letters every two weeks - this bundle of love and caring warms my heart and brings with it the will to live." ${ }^{80}$ Yet, Olga also recalls with horror a terrible moment when she cared more about her own survival than about her daughter. This in her memory becomes one of the harshest blows the camps delivered to her. One day she was told of a surprise awaiting her in the barrack: "I ran to the bed and threw off the pillow. Under it lay three letters from home, three letters! For half a year I had not received a single letter. The first feeling I experienced was sharp disappointment: it was not bread, it was letters! But following that reaction came horror ... Photographs fell out ... I forgot about the bread and I cried." 81 The reality of her disappointment at getting a letter rather than bread chilled and sickened her, but as she recalls, she could 
not help herself. Clearly this moment was deeply embedded in her psyche as one of the most devastating in her camp life.

Nadezhda attributes her survival to Lera, the child she gave birth to in the camps: "I hardly would have emerged alive from the meatgrinder if not for the baby." 82 In the short term alone, having an infant brought higher rations and release from physical labor. ${ }^{83}$ Nadezhda, though, condemns those who felt that survival for one's children justified immoral actions, such as forging bonds with criminal prisoners in order to get easier jobs or better rations. ${ }^{84}$ Olga as well states repeatedly that she knew she had to survive for her children. Yet at the same time, she admits that when she faced death, it took her mother's image in a dream to remind her of her moral duty. As she lay exhausted in a snowdrift, thinking she could just lie there and die, it was her mother whom she describes as appearing to her and speaking the words she needed to hear in order to get up and keep walking: "You will die, you will be resting, and what about me? I will have to live with the thought that I'll never see you again, that you died in a snowdrift? I have no right to die. I have your children on my hands." This reconstructed dream sequence reveals how it was both as a daughter and a mother that she found the strength to overcome this potentially fatal moment. ${ }^{85}$

Of the four memoirists, it is Valentina who refers the least to her motherhood as her reason for surviving. Rather, she emphasizes the importance of her own strong will, and the agency imparted to her by her beauty. She protected herself through defensive relations with men, her ability to use her sexuality to gain advantages, and her involvement in camp cultural productions. At one point, she claims that she was so passionately in love with a fellow prisoner that had she been freed at that moment, she would have refused to leave. Yet even Valentina maintains that she worried about her daughter, particularly after her mother died, and that her only plan after release was to retrieve her from the children's home. ${ }^{86}$

\section{Motherhood and the Camp Experience}

How did being a mother shape daily existence in the camps, social connectivity, and a woman's relations with authority? Nadezhda was the only one to give birth while in the camps, and to have a child with her through her term. It was daunting, for she could never separate either physically or emotionally from her responsibility as a mother. She had to keep her daughter alive and healthy in the face of circumstances she could neither alter nor control. Nor could she comfort herself that if something happened to her, it would be possible for relatives to come to Magadan and take the baby home with them, especially after her own mother was arrested. Lera would disappear into the NKVD system of orphanages. Nadezhda knew that only she could help her camp baby to survive.

Motherhood for Nadezhda, particularly during the first year of Lera's life, gave her some degree of agency while also allowing her to engage in familiar routines of childcare that constituted normal life outside the Gulag, even if made more difficult by camp conditions. Nadezhda had to wash cloths she used for diapers by hand every day in subfreezing temperatures. She had to breastfeed while living on a diet of soup 
and bread, and so could not maintain a healthy milk supply, for even extra rations for mothers were not adequate. Furthermore, Nadezhda had to trade some of her provisions to bribe a guard to bring extra wood for the one stove in the middle of the tent. She contracted mastitis, but ended up in a hospital with a sympathetic prisoner-doctor who extended her stay there by two months. One ruse was that she kept on "breastfeeding" past the normal time, despite a lack of milk, because this way she could see her baby every day; luckily for her, the kind doctor knew she lacked milk but still kept prescribing breast milk for the baby. ${ }^{87}$ Nadezhda eventually had to put her daughter in various nurseries attached to the Magadan camp system, some of which had horrific conditions. She describes one in hellish terms where illness caused death rates so shockingly high that finally the camp administration felt compelled to investigate. Her daughter was one of only three infants to survive, though she developed a heart condition. Tragically, a fellow prisoner's daughter, born at the same time as Nadezhda's, died from these conditions. ${ }^{88}$

Motherhood spurred Nadezhda to stand up for her rights as a mother. At one point while Lera was still in the barracks with her, Colonel Granin, the head of the Kolyma camp administration, did a surprise inspection and came into where she was staying. When he asked if they had any complaints, she spoke out, saying that the stove should be heated, that they should have more wood, and that the infants born in the camp needed milk. According to Nadezhda, the colonel agreed to everything, and she was transferred to a special camp sector for mothers where provisions were slightly better. ${ }^{89}$ She later describes periods when she was separated from her daughter for as long as six months, and had to take great risks to go and see her, bribing and trading extra rations for access. At one point she left the camp dressed in civilian clothes to go to a regional administrator to demand milk and easier access to her child. ${ }^{90}$ The obligation to keep her daughter alive outweighed the fear of retribution. Another such incident was when her daughter had a massive boil that had to be lanced, and the attending surgeon was clearly drunk. Nadezhda had to pitch a frenzied fit to ensure that a more capable set of hands would do the operation, and she succeeded. ${ }^{91}$

Nadezhda clearly took risks in challenging the authorities; such actions could lead to harsh punishments that could dehydrate and debilitate already weakened prisoners. Yet, as Nadezhda recalls such assertive behaviors, her memory imparts to them a sense of empowerment that in hindsight she suggests was crucial for her, and it certainly did enable her to keep Lera if not in the same camp, in the same general area, a situation many Gulag mothers were denied. As a Left Oppositionist who was a genuine political opponent of the Stalinist regime, Nadezhda despised making compromises with the camp administration. As a memoirist, she finds gratification in recounting her experiences as a mother, and what she did to defend her child. Tellingly, in the instances when she did confront camp authority, or push limits, it was in her capacity as a mother, not as a political oppositionist. Nonetheless, having her child with her also made her more vulnerable and, at times, more compliant. As a mother she had an Achilles' heel that camp authorities willingly used against her. They would threaten to transfer Nadezhda away from her daughter, or to put Lera in an NKVD orphanage if Nadezhda refused to cooperate. ${ }^{92}$ 
Liudmila's determination as a mother gave her agency from the moment of her arrest. When the NKVD came for her, she vociferously demanded the right to summon a fellow prisoner to stay with her daughter temporarily as well as to send a telegram to her sister-in-law in Leningrad asking her to come and get Elena. At first the NKVD men refused, but after Liudmila threatened to awaken the entire village, they relented. ${ }^{93}$ For Liudmila, connectivity with her daughter was paramount and protecting this link determined her responses to fellow prisoners and to situations that arose. Because Elena's letters were her sole source of comfort, Liudmila could not let anything interfere in her correspondence. The greatest threat to this lifeline came with the German invasion in 1941-security concerns led camp officials to destroy all incoming letters. One day Liudmila astutely noticed a young girl who worked for the NKVD boss in the camp carrying bundles to be burned, and she figured out that these were letters. Liudmila took a chance and asked her to put aside Liudmila's letters from her daughter. Liudmila bribed her with items from the packages sent by her daughter and sister-in-law, particularly clothing from Paris. Such an arrangement could have gotten her into trouble, but she did not think twice about making this deal, because she could not contemplate months or years without contact with her daughter. She notes as well that this continued connection preserved her sanity. As the war went on, rumors began to spread about the ghastly siege of Leningrad, but thanks to the letters she still received, she knew that her daughter had been evacuated..$^{94}$

The memoirs reveal how being a mother influenced their interactions with fellow prisoners. Liudmila's determination to survive for her daughter shaped her responses to other prisoners, and to particular moral challenges she faced. The few fellow prisoners that she describes are mainly mothers like herself, trying to endure separation from children or coping with the death of a child. Rather uniquely as a memoirist, she also includes in her narrative two instances when she consciously remained silent and chose not to help persons being tormented by criminal prisoners. She provides an excruciatingly detailed description of what happened to each of these individuals, in what could be interpreted as a sense of remorse for her nonaction. ${ }^{95}$ For her, though, in each case she cannot find fault with herself, even in hindsight. She knows that she chose to remain silent because she felt she could not take risks and jeopardize her own survival; protesting could have either led to her own death or to an additional sentence. In this case motherhood did not spur agency but rather self-protection, but both responses to her camp environment were rooted in her commitment to survive for her daughter.

Nadezhda and Olga gravitated toward prisoners who were mothers and include in their memoirs many references to them. Many of the prisoners they each describe are mothers separated from their children, suggesting that the plight of mothers left a deep imprint on their consciousness, and that they consciously sought to tell such stories to expose the brutality of a regime willing to shatter the most sacred of human bonds in order to serve its own political ends. Nadezhda describes tragic situations involving fellow prisoners who were mothers. She recounts a horrific scene of a woman who came into the barracks with a six-month-old baby. A group of men followed her in and lured the baby away from her with a set of keys. As the woman screamed, they 
gave the baby to the barracks attendant. Such images were seared in her memory because they constituted her worst fears of what might happen to Lera, and they tore at what she saw as the very fabric of the family bond sustaining her. ${ }^{96}$

One of the most gripping stories that Olga tells is what happened to Nadezhda Grankina, whose daughter died in the siege of Leningrad while living with her grandmother after her mother's arrest. Olga came to know Grankina well, and provides the tragic epilogue to the latter's story. Grankina survived the camps, only to find out later the horrific details of her daughter's death (she was beaten to death for her ration card). This revelation broke her emotionally, and in Olga's view, brought on a fatal stroke. ${ }^{97}$ Olga's own disrupted relationship with her children led her to find solace in helping young women and men who were trying to survive on their own, just as she imagined her own children doing: "I imagined my daughter in these bunks, frightened and not understanding anything . . . That was when I turned gray." ${ }^{98}$ She describes how she found an outlet for her maternal instincts by serving as a mother figure, especially during her second arrest in 1949: "Gradually a young girl's club gets organized on my bunk. I am very much afraid of getting sent to a camp instead of into exile but I don't have the strength to restrain myself from comforting my girls." ${ }^{99}$ She includes a long section on the children of 1937-1938 who were arrested with her in 1949. They were good for her, she recalls, because it allowed her to do for them what she had not been able to do with her own children, and she was good for them, because they were frightened and inexperienced. ${ }^{100}$

\section{The Impact of the Gulag on Mothers and Children}

Survival did not end with the women's release from the camps. They faced new challenges after leaving the Gulag. Often the reunions between freed mothers and their children could be strained and awkward, with neither knowing the other after years of being apart. To protect the children, caretakers were often afraid to affirm the innocence of the arrested parents, or in some cases even blamed them for getting involved in nefarious political activities. ${ }^{101}$ For these four prisoner mothers, post-Gulag reunions included some of these difficulties, but to varying degrees. Olga's initial reunion with her children after her first release, especially her son, who had grown into a staunch supporter of Stalin and the Soviet regime, was difficult, but they were able to work out over time a strong relationship. After the camps she enjoyed a long life, and was able to see both of her children achieve successful lives and careers. She died quietly in her son's home in 1991. For Olga, being in the camps tore her from her children, but her larger family and kin network held strong, and facilitated her ability to reunite with her children. The final chapters in her memoir pay tribute to the sacrifices and support of her extended family and the courage of her children. ${ }^{102}$

Valentina was more fortunate than many parents whose children ended up in an orphanage; she was able to retrieve her daughter, and according to biographical information, she went on to have five more children with two different husbands. The memoir in general reflects greater concern with how the Gulag interfered with her aspirations to be an actress than with the impact it had on her motherhood, perhaps be- 
cause in the long run she felt its impact less in terms of her maternal identity. Valentina was very young when she was arrested, only eighteen, and had only been a mother for a short period of time; the camps did not for her mean a disruption in a routine of family life with husband and children to the same degree as with the other three memoirists. ${ }^{103}$ Unlike Nadezhda, she did not find agency in the camps through her assertion of her maternal identity, but through her sexuality and her talents as an actress and singer, and this is what she projects in her memoir. Yet, in a 2001 interview with a group of schoolchildren, Valentina told them that while she was in prison she nearly went mad from missing her infant daughter and that throughout her time in the camps she knew she had to survive because she had to get her daughter out of the orphanage. Memory, like survival itself, is a complex phenomenon, situational and multifaceted. While writing her memoir, Valentina may have preferred dwelling on her personal loves and artistic triumphs in the camps, but the children she spoke with wanted to know about Bella, and she spoke at greater length about what it meant to be a mother in the camps. ${ }^{104}$

Nadezhda recounts a long and arduous process of reuniting with her daughters after her release in 1941 from the camps. It was not achieved fully until after Stalin's death. Her task was made more difficult by the arrest of her own mother, severe restrictions on ex-prisoners, the German invasion and the outbreak of war, as well as her second arrest in 1949. During the war, she had to stay in Magadan and could not correspond with her daughters, who eventually ended up in Baku with their great-uncle. Only later did Nadezhda learn the truth about her oldest daughters' harrowing experiences. She includes in the memoir a statement from Natasha, the eldest, detailing the horrific ordeals they suffered, being shuffled around from one relative to another, and ending up during the war in Moscow without food or any adults to care for them. ${ }^{105}$ Nadezhda had Lera with her in Magadan, but felt vulnerable, and attached herself to a former criminal prisoner who was working as a bookkeeper; he won her over by assuring her that if anything happened to her, he would take Lera to Baku to be with her sisters. She ended up having a fourth daughter by him, though their relationship ended once Nadezhda could leave Magadan in 1946. She took Lera and tried to build a life in Azerbaijan with her two oldest daughters, Natasha and Kira, but her second arrest disrupted this. Kira went back to her great-uncle in Baku, and she chose to stay in Azerbaijan with her adopted family. Lera lived with Nadezhda's mother, but ended up in an orphanage for a time without Nadezhda's knowledge. Eventually, after Stalin's death in 1953 and her own rehabilitation, Nadezhda achieved what had become her single-minded purpose: "I dreamed of one thing only - to get a job somewhere and bring all my children together." 106 She had to lobby relentlessly for the right to have an apartment large enough to allow her daughters to live with her, and particularly to have her oldest daughter, Natasha, who was married at the time, be allowed to join her there in Moscow. Nadezhda recalls telling one official who claimed that a married daughter did not need to live with her mother that "her [Natasha's] right consisted precisely in the fact that from the age of six, she hadn't been allowed to live 'with her mama.'"107 In the end, three of her four daughters, Natasha, Lera, and Larissa, the daughter born during the war while Nadezhda was in Magadan, moved in with her in Moscow. Her family emigrated to New York after the fall of the Soviet Union, and all four of her daughters celebrated her ninetieth birthday with her in Brooklyn in 
1996. Nadezhda died in 1999. ${ }^{108}$ Nadezhda's memoir is the most politically oriented of the four memoirs, yet she ends it not with politics, but with the reconstruction of her maternity and her family unit. The final triumph is the ability to preserve a bond with her children, and to restore the grave of her father in Novodeichy Cemetery. For Nadezhda, the camps strengthened her maternal identity, and the memoir develops into the story of a mother whose children were cast by Stalinism into alien and at times dangerous environments. The measure of her triumph over this evil was her capacity to reconstitute the private familial bonds targeted by the state.

Liudmila's post-Gulag relationship with her daughter turned out to be the most tragic of the four. Liudmila did not get to reconstruct her family after her release and rehabilitation. The tragedy of her physical separation from her daughter was compounded by the fact that the emotional connection they once had was never restored; her daughter had become much closer to her aunt, whom she came to address as "mother," even after Liudmila's return. Then in 1958, her daughter died prematurely from an infection stemming from a miscarriage that had occurred several years earlier, while Liudmila was still living in exile. Liudmila's memoir brings out the agony Liudmila felt as she sought to advise her daughter through these medical crises, but their estrangement meant that Elena did not trust her mother's advice. Elena followed the procedures laid out by her aunt's doctors, which were different from what Liudmila felt should be done; as a memoirist, Liudmila cannot help agonizing over the fact that her daughter might have been saved if only her role as mother had not been compromised by her imprisonment. Thus in her mind, the Gulag had destroyed what had meant more to Liudmila than any other facet of her life-her relationship with her daughter, which had been her only motivation for surviving her Viatka imprisonment. The maternal subjectivity informing her camp narrative stems from the fact that the Gulag shattered her maternal identity, and this is what haunts her memory. Liudmila's memoir, written during the last year of her life, testifies to the terrible personal price individuals such as herself paid for Stalinist policies that punished the innocent with no concern for the "collateral damage." For Liudmila, there was no happy ending, and she offers her story as a profound personal indictment of the Stalinist terror and its chief instrument, the Gulag.

There is an irony in the impact of the Gulag on mothers. For many, the very same familial kinship bonds that had provided the foundation for their incarceration were what sustained their spirit and fortified their endurance; in the case of these four women, their camp experiences ended up damaging, but not destroying these bonds, and made them upon release staunchly determined to reconstitute them as best they could. Women were punished in Stalinist Russia for patriarchal conceptions of their weakness and vulnerability to the influence of husbands, fathers, and brothers who had turned "traitor"; yet their gendered identity as mothers and caretakers of the family empowered them to survive. Motherhood reminded them that they had a life, a web of connectivity outside the camps that they could return to, if only they could endure. The human bond intrinsic to motherhood defied the conscious efforts of Gulag administrators to break the will, spirit, and humanity of prisoners. It was the personal side of themselves these women clung to when so much else that was dear to them had been taken from them-husbands, professions, parents, and political ideals. 


\section{Conclusion}

A study of motherhood in the Gulag reveals the complexities of gender in Stalinist society. The initial revolutionary ideals of separating women from traditional gender roles were subsumed in the 1930s by renewed emphasis on women's feminine qualities and the celebration of motherhood. In 1935, the state publicly declared that the Communist Party was "exceptionally" attentive to motherhood, that Soviet children were "the healthiest children," and that motherhood had become "joyful." Nonetheless the terror of 1937-1938 targeted wives and mothers as suspect and weak, easily infected by the potential poison of treason, and who needed to be exiled or incarcerated themselves to stem the contagion. ${ }^{109}$ Motherhood was sacrosanct in Stalinist propaganda, yet vulnerable to the arbitrary blows of political terror. In the camps women experienced "equality" in that they performed debilitating manual labor tasks such as tree felling and ditch digging, often working side by side with men, though women were also more likely to be assigned to tasks traditionally associated with women such as agricultural labor and textiles. Yet women suffered from hardships in the camps that were rooted in gender differences rarely taken into account. Camp administrators left women's biological needs neglected and subjected them to violence, not only that accorded to prisoners in general, but to sexual violence from authorities as well as other prisoners (usually criminal prisoners). ${ }^{110}$ The Gulag administration made accommodations for women to have children, yet did little to insure infants' and children's well-being, and allowed appalling conditions that proved fatal to so many.

Motherhood is one of the most gendered aspects of women's experience of the Gulag. Only women could become pregnant and endure the physical and psychological challenges of giving birth while incarcerated. Mothers in the Gulag who had to leave children behind certainly shared this agony with arrested fathers; yet women did bear both socially and personally constructed expectations that they were primarily responsible for childcare. Thus, many mothers in the Gulag felt intense guilt and anxiety at not being able to fulfill their children's needs. Motherhood complicated women's lives in the camps because of this added physical and psychological strain. For political prisoners, it magnified the already overwhelming trauma of false accusations, unjust and corrupted judicial processes, brutal treatment, and physical deprivation. Yet, as the stories of these four women show, it was also a source of strength that gave them a reason to keep going from day to day.

There is much more still to be explored. The women analyzed here shared common situations, vulnerabilities, and choices that distinguished them from childless women, male prisoners, and male memoirists; yet the memoirs also reveal striking differences in mothers' experiences, thus underscoring the need to examine more broadly how maternity, and gender as a whole, interacted with other factors to produce diverse patterns of survival among women. Further research is needed to determine how survival of women may have been shaped not just by their own consciousness as mothers but by objective conceptions of motherhood held by the camp administrators, guards, and political and criminal prisoners, which may have modified their treatment of women who were mothers. There are also further questions to be examined with regard to the social and cultural imperatives that operated, and to what extent their impact was re- 
fracted less through the lens of gender than through class and levels of education. An insightful direction would be to examine comparatively the experiences of mothers among a broader population of female prisoners, including nonpolitical and criminal prisoners. To what extent did these different categories of female prisoners accept the conceptualization of motherhood as a sacred duty, as Soviet propaganda had come to proclaim in the 1930s and 1940s? For Nadezhda, Olga, and Liudmila, coming from Jewish families may have informed their understandings of motherhood in similar ways, but more research is needed to explore how this may have shaped their maternal behavior and identity. Cross-cultural and transnational analysis of prisonermothers in concentration camps and prisons could illuminate what may have been distinctively Soviet or Russian features of motherhood in the Gulag. More work is needed to explore the interplay of maternity and memory in Gulag narratives; because the Gulag had such an impact upon children and families, this may produce a stronger role for it in the reconstructed camp narrative than perhaps it played during the actual camp experience. Yet, the absence of it in some women's narratives may not mean that maternity did not figure in their lives and survival, but that it is a theme too painful or too private to discuss. It would also be fruitful to examine how fathers experienced the camps, and analyze comparatively the extent to which references to children appear in male memoirs as well as in the increasing number of letters being made available to researchers. ${ }^{111}$

Motherhood shaped the camp lives of the four women profiled here in differing ways, and it figured differently in their memory as they wrote their camp narratives. But each accepted societal norms that as mothers they bore a special responsibility for their children. This imperative compelled them to survive, and it became a source for agency and opposition to the machinations of state terror. It drove them in its aftermath to restore the familial bonds that the state had shattered. That they were not all able to do so reminds us that, for many Gulag mothers and the children they left behind, the Stalinist terror was destructive and dysfunctional, leaving wounds that could never heal. The suffering of mothers in the camps illuminates poignantly the inhumanity of the Gulag, yet at the same time their resiliency in the face of personal tragedy helps us to understand how it was possible to endure and even overcome that inhumanity.

\section{$\diamond$ About the Author}

Elaine MacKinnon is a Professor of History at the University of West Georgia. She earned a PhD in modern European history from Emory University. Her publications include "The Forgotten Victims: Childhood and the Soviet Gulag, 1929-1953," The Carl Beck Papers in Russian and East European Studies, no. 2203 (University Library System, University of Pittsburgh Press, 2012) and "We Are Not Counterrevolutionaries! Soviet Tolstoyans and Their Fate, 1917-1939," Tolstoy Studies Journal 18 (2016): 1-12. She is currently working on an English-language translation of Liudmila Miklashevskaia's memoir Povtorenie proidennogo (Reliving the past: From memories), forthcoming with I. B. Taurus. E-mail: emcclarn@westga.edu 


\section{$\diamond$ Notes}

The author would like to thank the editors and reviewers of Aspasia for their careful reading, valued criticism, and editorial guidance that have helped shape this article, as well as Dr. Aran MacKinnon for his many useful stylistic suggestions and support.

1. Olga Adamova-Sliozberg, My Journey: How One Woman Survived Stalin's Gulag, trans. Katherine Gratwick Baker (Evanston, IL: Northwestern University Press, 2011); Liudmila Miklashevskaia, Povtorenie proidennogo: Iz vospominanii [Reliving the Past: From Memories], in Liudmila Miklashevskaia and Nina Katerli, Chemu svideteli my byli: Zhenskie sudby XX vek [What we witnessed: Women's fates in the 20th century] (St. Petersburg: Zvezda, 2007), 27-400; Nadezhda A. Joffe, Back in Time: My Life, My Fate, My Epoch, trans. Frederick S. Choate (Oak Park, MI: Labor Publications, 1995); Valentina Grigorievna Ievleva-Pavlenko, "Unedited Life," in Remembering the Darkness: Women in Soviet Prisons, ed. and trans. Veronica Shapovalov (New York: Rowman \& Littlefield Publishers, 2001), 317-354.

2. For an overview of recent literature on the camps, see Alan Barenberg, Wilson T. Bell, Sean Kinnear, Steven Maddox, and Lynne Viola, "New Directions in Gulag Studies: A Roundtable discussion," Canadian Slavonic Papers/Revue candaienne des slavistes 59, nos. 3-4 (2017): 376395; among the works discussed are Golfo Alexopoulos, Illness and Inhumanity in Stalin's Gulag, Yale-Hoover Series on Authoritarian Regimes (New Haven, CT: Yale University Press, 2017); Michael David-Fox, ed., The Soviet Gulag: Evidence, Interpretation, and Comparison (Pittsburgh: University of Pittsburgh Press, 2016); and Alan Barenberg, Gulag Town, Company Town: Forced Labor and its Legacy in Vorkuta (New Haven, CT: Yale University Press, 2014).

3. On death rates in the camps, see Alexopoulos, Illness and Inhumanity in Stalin's Gulag, 14-15; J. Arch Getty, Gabor T. Rittersporn, and Viktor N. Zemskov, "Victims of the Soviet Penal System in the Pre-War Years: A First Approach on the Basis of Archival Evidence," American Historical Review 98, no. 4 (October 1993): 1017-1049, here 1023-1025; Anne Applebaum, Gulag: A History (New York: Doubleday, 2003), 582-583; Steven A. Barnes, Death and Redemption: The Gulag and the Shaping of Soviet Society (Princeton, NJ: Princeton University Press, 2011), 76-77, 116.

4. On women's traditional role in Russian history, see Natalia Pushkareva, Women in Russian History: From the Tenth to the Twentieth Century, ed. and trans. Eve Levin, New Russian History Series (Armonk, NY: M. E. Sharpe, 1997); Barbara Alpern Engel, Women in Russia, 1700-2000 (Cambridge: Cambridge University Press, 2004); on the association of women with maternity in Russia, see Joanna Hubbs, Mother Russia: The Feminine Myth in Russian Culture (Bloomington: Indiana University Press, 1993).

5. Engel, Women in Russia, 175.

6. Ibid., 158-165. For discussion of women's changing roles in the Soviet period, particularly the tension between women's emancipation in terms of political and economic equality and the state's continued association of women with domestic duties and motherhood, see Lynne Attwood, Creating the New Soviet Woman (New York: St. Martens Press, 1999); Dorothy Atkinson et al., eds., Women in Russia (Stanford, CA: Stanford University Press, 1977); Wendy Z. Goldman, Women at the Gates: Gender, Politics and Planning in Soviet Industrialization (Cambridge: Cambridge University Press, 2002); Greta Bucher, Women, the Bureaucracy and Daily Life in Postwar Moscow, 1945-1953 (Boulder, CO: East European Monographs, 2006); and Anna Krylova, Soviet Women in Combat: A History of Violence on the Eastern Front (New York: Cambridge University Press, 2010).

7. Wilson T. Bell, "Sex, Pregnancy, and Power in the Late Stalinist Gulag," Journal of the History of Sexuality 24, no. 2 (May 2015): 198-224, here 221-222; Engel, Women in Russia, 177-178. 
8. Bucher, Women, the Bureaucracy and Daily Life, 12-18, discussed and cited in Bell, "Sex, Pregnancy, and Power," 222.

9. L. A. Maksimova, "Materinstvo v lageriakh GULAGa" [Maternity in the Gulag camps], in Gendernaia teoriia i istoricheskoe znanie: Materialy Mezhdunar. nauch.-prakt. konf. [Gender theory and historical knowledge: Materials of an international scientific-practical conference], ed. A. A. Pavlov (Syktyvkar: Syktyvkarskii gos. Universitet, 2003), 277-284, here 277.

10. Veronika Shapovalova, "Sestrenki, mamki, damki: Tema nasiliia v zhenskikh lagernykh memuarakh" [Sisters, moms, dames: The theme of violence in women's camp memoirs], in Bytovoe nasilie v istorii rossiiskoi povsednevnosti (XI-XXI vv): Kollektivnaia monografiia [Domestic violence in the history of Russian everyday life (19th to 20th centuries)], ed. M. G. Murav'eva and N. L. Pushkareva (St. Petersburg: Evropeiskii universitet v Sankt-Peterburge, 2012), 160-161.

11. Golfo Alexopoulos, "Stalin and the Politics of Kinship: Practices of Collective Punishment, 1920s-1940s," Comparative Studies in Society and History 50, no. 1 (January 2008): 91-117.

12. Golfo Alexopoulos, "Exiting the Gulag after War: Women, Invalids and the Family," Jahrbücher für Geschichte Osteuropas 57 (2009): 563-579.

13. Bell, "Sex, Pregnancy, and Power in the Late Stalinist Gulag," 221, and for the quotation, 224.

14. See Simon Vilensky, ed., Till My Tale Is Told: Women's Memoirs of the Gulag (Bloomington: University of Indiana Press, 1999); Shapovalov, Remembering the Darkness; Jehanne M. Gheith and Katherine R. Jolluck, Gulag Voices: Oral Histories of Soviet Incarceration and Exile (New York: Palgrave MacMillan, 2011); and Anne Applebaum, ed., Gulag Voices: An Anthology (New Haven, CT: Yale University Press, 2011).

15. Aleksandr Solzhenitsyn, The Gulag Archipelago 1918-1956: An Experiment in Literary Investigation, vols. 3-4, trans. Thomas P. Whitney (New York: Harper \& Row, 1975), 227-250, here 242-244.

16. Applebaum, Gulag, 317-327.

17. Emma Mason, "Women in the Gulag in the 1930s," in Women in the Stalin Era, ed. Melanie Ilič (New York: Palgrave, 2001), 131-150, here 141-144.

18. L. Dolzhanskaia and I. Osipova, eds., "Dorogaia Ekaterina Pavlovna ..." Pis'ma zhenshchin $i$ detei. Pis'ma v ikh zashchitu 1920-1936. Po dokumentam fondov: "Moskovskii Politicheskii Krasnyi Krest," "E. P. Peshkova: Pomoshch' politicheskim zakliuchennym" ["Dear Ekaterina Pavlovna ..." Letters of women and children. Letters in their defense 1920-1936. From the archival fonds of the Moscow Political Red Cross and E. P. Peshkova: Aid to political prisoners] (St. Petersburg: Zhurnal Zvezda, 2005).

19. Simeon Vilensky, ed., Deti GULAGa: 1918-1956 [Children of the Gulag: 1918-1956] (Moscow: Demokratiia, 2002); published in English and with added commentary as Cathy A. Frierson and Semyon S. Vilensky, eds., Children of the Gulag (New Haven, CT: Yale University Press, 2010).

20. O. I. Chesnokova, “Zhenskii opyt GULAGa v sovetskoi istorii 1930-1950-kh godov [Gulag women's experience in Soviet history 1930-1950], in Zhenshchiny $v$ istorii: Vozmozhnost' byt' uvidennymi-sbornik nauchnykh statei [Women in history: The opportunity to be seen-a collection of scientific articles], ed. I. R. Chikalov (Minsk: BGPU im. Maksima Tanka, 2001), 189-193; Oksana Kis', “Zhinochii dosvid GULAGu: Stan doslidzhen' ta dzerel'ni resursi v Ukrains'komu konteksti-chastina I" [The Gulag women's experience: The state of research and resources in the Ukrainian context-part I], Historians, 22 November 2013, http://www.historians.in.ua/index. php/en/component/content/article/21-doslidzhennya/943-oksana-kis-zhinochyy-dosvid-hulahu-stan-doslidzhen-ta-dzherelni-resursy-v-ukrayinskomu-konteksti-chastyna-i?itemid=149(accessed 12 February 2019); Oksana Kis', “Zhinochii dosvid GULAGu: Stan doslidzhen' ta 
dzerel'ni resursi v Ukrains'komu konteksti-chastina II" [The Gulag women's experience: The state of research and resources in the Ukrainian context-part II], Historians, 28 November 2013, http://www.historians.in.ua/index.php/en/component/content/article/21-doslidzhennya/ 957-oksana-kis-zhinochyy-dosvid-hulahu-stan-doslidzhen-ta-dzherelni-resursy-v-ukrayinskomu-konteksti-chastyna-ii?itemid=149 (accessed 12 February 2019); V. Gritsenko, "Zhenskoe litso GULAGa: Kak na Mertvoi doroge roslo naselenie SSSR" [The female face of the Gulag: How the population of the USSR grew along the road of death], Novaia Gazeta [New Gazette], 13 April 2009, http://cripo.com.ua/stories/?p=70371/ (accessed 12 February 2019); V. Shapovalova, "Lager' kak obraz zhizni: Zhenskie lagernye memuary" [The camp as a way of life: Women's camp memoirs], in Sotsial'naia istoriia: Ezhegodnik 2003, zhenskaia i gendernaia istoriia [Social history: Yearbook 2003, women's and gender history], ed. N. L. Pushkareva (Moscow: ROSSPEN, 2003), 465-487; V. Kuzin, "Zhenshchiny GULAGa” [Women in the Gulag], Grani epokhi: Etikofilosofskii zhurnal [The edge of the epoch: An ethical philosophical journal], no. 32 (2007), http:// www.facets/ru/articles7/3210htm (accessed 12 February 2019); T. Vronskaia, “Karatel'naia politika $\mathrm{v}$ otnoshenii zhenshchin i detei $\mathrm{v}$ sutki Bol'shogo Terrora" [Penal policy toward women and children during the days of the Great Terror], in T. Vronskaia, Upokoreniia strakhom: Semeinoie zalozhnichestvo v karatel'noi praktike sovetskoi vlasti (1917-1953 gg) [Pacifying with fear: The family hostage system in Soviet penal policy (1917-1953)] (Kiev: Tempora, 2013), 142-192.

21. Shapovalova, "Sestrenki, mamki, damki," 157-158 and 160-161; and Maksimova, "Materinstvo v lageriakh GULAGa," 277-278.

22. Orlando Figes, Just Send Me Word: A True Story of Love and Survival in the Gulag (New York: Metropolitan Books, 2012); also see his earlier work, The Whisperers: Private Life in Stalin's Russia (New York: Metropolitan Books, 2007); for a similar approach of examining women through personal case studies, see Paul R. Gregory, Women of the Gulag: Portraits of Five Remarkable Lives (Stanford, CA: Hoover Institution Press, 2013).

23. Leona Toker, Return from the Archipelago: Narratives of Gulag Survivors (Bloomington: Indiana University Press, 2000); Darius Tolczyk, See No Evil: Literary Cover-Ups and Discoveries of the Soviet Camp Experience (New Haven, CT: Yale University Press, 1999); Shapovalova, "Sestrenki, mamki, damki," 145. For discussion of the value of women's memoirs as historical sources, see Andreas Lixl-Purcell, "Memoirs as History," Leo Baeck Institute Yearbook 39, no. 1 (1994): 227-238.

24. Gheith and Jolluck, Gulag Voices, 8-9; Nanci Adler, The Gulag Survivor: Beyond the Soviet System (New Brunswick, NJ: Transaction Publishers, 2002), 40; Daniel Bertaux, Paul Thompson, and Anna Rorirch, eds., On Living Through Soviet Russia (London: Routledge, 2004), 10.

25. See Shapovalova, "Sestrenki, mamki, damki," 146-147.

26. Irina Paperno, Stories of the Soviet Experience: Memoirs, Diaries, Dreams (Ithaca, NY: Cornell University Press, 2009), 9-14; see also on the value of survivor testimony, Nanci Adler and Selma Leydesdorff, eds., Tapestry of Memory: Evidence and Testimony in Life-Story Narratives (Piscataway, NJ: Transaction Publishers, 2013). On the significance of memoir for studying gender in Russian history, see Beth Holmgren, The Russian Memoir: History and Literature (Evanston, IL: Northwestern University Press, 2007); and her Women's Works in Stalin's Time: On Lidia Chukovskaya and Nadezhda Mandelshtam (Bloomington: Indiana University Press, 1993).

27. Veronica Shapovalov, "Introduction," in Shapovalov, Remembering the Darkness, 3.

28. Barbara Clements, Bolshevik Women (New York: Cambridge University Press, 1997), 280; Engel, Women in Russia, 183.

29. Shapovalov, "Introduction," 7-11; Bell, "Sex, Pregnancy and Power," 206-207; see also Donald Filtzer, Soviet Workers and Late Stalinism: Labour and the Restoration of the Stalinist System after World War II (Cambridge: University of Cambridge Press, 2002), 27. 
30. Clements, Bolshevik Women, 279-280; for discussion of the motives and mind-set behind such arrests, see Alexopoulos, "Stalin and the Politics of Kinship," 104-107. On the Akmola camp, see David Trilling and Joanna Lillis, "The Forgotten Women of the Gulag," Eurasianet, 6 August 2009, https://eurasianet.org/the-forgotten-women-of-the-gulag (accessed 20 October 2018); Dmitry Lee, "ALZHIR Memorial Tells Stories of Soviet Union's Imprisoned Wives," The Astana Times, 22 April 2016, https://astanatimes.com/2016/04/alzhir/ (accessed 20 October 2018).

31. “Operativnyi prikaz narodnogo komissara vnutrennikh del SSSR No 00486 'Ob operatsii po repressirovaniiu zhen i detei izmennikov rodiny,' 15 avgusta 1937 g." [Operational order no. 00486 of the People's Commissar of Internal Affairs of the USSR: "On the operation to repress wives and children of traitors to the motherland," 15 August 1937], Informatsionnyi biuleten' Pravleniia Mezhdunarodnogo istoriko-prosvetitel'skogo blagotvoritel'nogo i pravozashchitnogo obshchestva 'Memorial' [Newsletter of the Board of Memorial: An International Historical, Educational, Human Rights and Charitable Society], no. 12 (1999): 19-21, in Vilensky, Deti GULAGa, 234-238; translated and discussed in Frierson and Vilensky, Children of the Gulag, 157-162, here 157-158. See also Mason, "Women in the Gulag in the 1930s," 133.

32. The source for the 1940 figure and the percentage of women in 1955 is Getty et al., "Victims of the Soviet Penal System in the Pre-War Years," 1025; the authors record women as 24 percent in 1945, but other studies show a higher percentage. For higher estimates, see Applebaum, Gulag, 315-316; Bell, "Sex, Pregnancy and Power," 206; G. Ivanova, "GULAG: Gosudarstvo v gosudarstve" [The Gulag: A state within a state], in Sovetskoe obshchestvo: Vozniknovenie - razvitieisstoricheskii final [Soviet society: Emergence-development-historical finale], vol. 2, ed. Iu. N. Afanas'iev (Moscow, 1997): 216-217, cited by Kis', "Zhinochii dosvid GULAGu," part 1; Mason, "Women in the Gulag in the 1930s," 132-133; for other figures, see A. B. Bezborodov and V. M. Khrustalev, eds., Istoriya stalinskogo GULAGa: Konets 1920-kh-pervaya polovina 1950-kh godov, vol. 4, Naselenie GULAGa: Chislennost' i usloviya soderzhaniya [The history of the Stalinist Gulag: From the end of the 1920s to the first half of the 1950s, vol. 4, The population of the Gulag: The number and conditions of detention] (Moscow: ROSSPEN, 2004), 75, 98-99, discussed and cited in Alexopoulos, "Exiting the Gulag after War," 567-568.

33. Alexopoulos, "Exiting the Gulag after War," 568.

34. Applebaum, Gulag, 311; Bell, "Sex, Pregnancy, and Power," 206.

35. Shapovalova, "Sestrenki, mamki, damki," 159-162; Kuzin, "Zhenshchiny Gulaga."

36. Frierson and Vilensky, Children of the Gulag, 228-231 and 241-242; see also Shapovalova, "Sestrenki, mamki, damki," 161.

37. Liudmilla Ivanovna Granovskaia, "From Aelita's Notes," in Shapovalov, Remembering the Darkness, 244-252, here 248-249.

38. See discussion in Bell, "Sex, Pregnancy, and Power," 202 and 220-221. He views Nazi racial policies as the most important factor contributing to differences in treatment of pregnancy in the two concentration camp systems.

39. Vilensky, Deti GULAGa, 571n62; see also Frierson and Vilensky, Children of the Gulag, 213-214.

40. See Applebaum, Gulag, 319; Shapovalova, "Sestrenki, mamki, damki," 156-157; Maksimova, "Materinstvo v lageriakh GULAGa," 279-280.

41. Bell, "Sex, Pregnancy, and Power," 200 and 218-219.

42. Just in one year, from 1948 to 1949, the number of women prisoners with children had risen by 138 percent and the number of pregnant women by 98 percent. Vilensky, Deti GULAGa, 571n62; see also N. V. Petrov, Istoriia imperii "Gulag" [The history of the Gulag empire], chap. 17, http://www.pseudology.org/GULAG/Glava17.htm (accessed 10 February 2019); Solzhenitsyn, The Gulag Archipelago, 246-247. Some scholars attribute the rise in pregnancies to longer sen- 
tences being handed out to women and less likelihood of returning to their families, but also suggest that the postwar amnesties themselves offered a strong incentive for getting pregnant. See Gritsenko, "Zhenskoe litso GULAGa."

43. Bell, "Sex, Pregnancy, and Power," 216.

44. Such numbers do not seem to have been kept. See Shapovalova, "Sestrenki, mamki, damki," 156.

45. "Zapiska nachal'nika Gulaga NKVD SSSR V. G. Nasedkina narkomu vnutrennikh del SSSR L. P. Beriia, 19 aprelia 1941 g." [Memorandum of the chief of the Gulag V. G. Nasedkin to the USSR Commissar of Internal Affairs L. P. Beria, 19 April 1941], Gosudarstvennyi arkhiv Rossiiskoi Federatsii [State Archive of the Russian Federation, hereafter GARF], fond 9414, opis 1, delo 42, 11. 26-27 (19 April 1941), reprinted in Vilensky, Deti GULAGa, 366-367; Bell, "Sex, Pregnancy, and Power," 218-219; see also discussion in Elaine MacKinnon, "The Forgotten Victims: Childhood and the Soviet Gulag, 1923-1953," The Carl Beck Papers in Russian and East European Studies, no. 2203 (September 2012): 12-13.

46. Alexopoulos, "Exiting the Gulag after War," 568n32.

47. Shapovalova, "Sestrenki, mamki, damki," 149-153; Maksimova, "Materinstvo v lageriakh GULAGa," 277-278; Bell, "Sex, Pregnancy, and Power," 199 and 212-213; Gritsenko and Kalinin, "Zhenskoe litso GULAGa." According to David Trilling and Joanna Lillis, in the Alzhir women's camp between 1938 and 1953, there were 1,507 births due to prisoners being raped by guards. They do not cite the source for this figure, however. See Trilling and Lillis, "The Forgotten Women of the Gulag," 2.

48. Bell, "Sex, Pregnancy, and Power," 203-204; Solzhenitsyn, The Gulag Archipelago, 248249; Chesnokova, "Zhenskii opyt Gulaga v sovetskoi istorii," 191-192; Maksimova, "Materinstvo v lageriakh GULAGa," 277-280; Gritsenko and Kalinin, "Zhenskoe litso GULAGa."

49. Shapovalova, "Sestrenki, mamki, damki," 157.

50. Applebaum, Gulag, 318-320; Shapovalova, "Sestrenki, mamki, damki," 158-159. Shapovalova notes that many memoirists claim that criminal prisoners were more likely to seek pregnancy as a means for getting higher rations and lighter work.

51. Bell, "Sex, Pregnancy, and Power," 216.

52. Frierson and Vilensky, Children of the Gulag, 213; Mason, "Women in the Gulag in the 1930s," 141.

53. Hilda Vitzthum, Torn by the Roots: The Recollections of a Former Communist, trans. Paul Schach (Lincoln: University of Nebraska Press, 1993), 179.

54. Maksimova, "Materinstvo v lageriakh GULAGa," 284.

55. Bell, "Sex, Pregnancy, and Power," 216-217.

56. According to Emma Mason, nonnursing mothers could only see their babies on the sixth and twenty-fourth days of the month and only between the hours of five and six. See Mason, "Women in the Gulag in the 1930s," 142-143; Shapovalov, "Introduction," 9-10.

57. Maksimova, "Materinstvo v lageriakh GULAGa," 280-281; Kuzin, "Zhenshchiny Gulaga." During a recent interview, a woman born in the Gulag told of how her twin brother died in the camp nursery from lack of food, care, and medicine. After seventy years, what she remembered best was the constant state of hunger she felt until she and her mother left the camp when she was six. See James Bartholomew, "'My Life in a Gulag': The Horror of Stalin's Prison Camps," The Spectator, 20 May 2017, https://www.spectator.co.uk/2017/05/my-life-in-a-gulagthe-horror-of-stalins-prison-camps/ (accessed 20 October 2018).

58. Mason, "Women in the Gulag in the 1930s," 144; Bell, "Sex, Pregnancy, and Power," 217; Maksimova, "Materinstvo v lageriakh GULAGa," 280-284; Gritsenko and Kalinin, "Zhenskoe litso GULAGa," 6-7; Applebaum, Gulag, 322-325. For more discussion of what happened to children who ended up in NKVD orphanages, see Frierson and Vilensky, Children of the Gulag; 
and Deborah Hoffman, trans. and ed., The Littlest Enemies: Children in the Shadow of the Gulag (Bloomington, IN: Slavica, 2009).

59. Maksimova, "Materinstvo v lageriakh GULAGa," 282-284.

60. Hava Volovich, "My Past," in Vilensky, Till My Tale Is Told, 260-262. In a letter sent to Memorial, N. S. Zubova, who was sentenced in 1948 while pregnant and gave birth in a mother's camp, claimed that on a daily basis, thirty to thirty-five children died of starvation. See Frierson and Vilensky, Children of the Gulag, 308.

61. Pavlenko, "Unedited Life," 317-318.

62. In her memoir, Valentina does not clearly identify who the father of Bella is, leaving it open to the possibility that it could have been either an American naval officer or the Russian sailor Kostia, with whom she says she had a common-law marriage at the time of her arrest. But in a 2001 interview with schoolchildren, she told them that Bella's father was an American who left with his ship during the war and that she never heard from him again. See V. G. Ievleva, “Vstrecha s shkol'nikami: Vstrecha Valentiny Grigor'ievny Ievlevoi, byvshei uznitsy GULAGa s shkol'nikami 31.05.2001 goda" [A meeting with schoolchildren: A meeting of Valentina Grigor'ievna Ievleva, former prisoner in the Gulag, with schoolchildren, 31 May 2001], Vospominaniia o GULAGe i ikh avtory, Sakharovskii tsentr [Remembrances of the Gulag and their authors, Sakharov Center], https://www.sakharov-center.ru/asfod/auth/?t=unpubli shed\&syn=254 (accessed 12 February 2019).

63. The majority of prisoners seem to have been workers and peasants rather than intellectuals, though the number of political prisoners rose above 50 percent beginning in 1939 and remained high through the war and afterward in certain hard labor camps set up just for political prisoners. See V. N. Zemskov, “Zaklyuchennie 1930-e gody: Sotsial'no-demograficheskie problemy" [Prisoners in the 1930s: A social-demographic problem], Otechestvennaia istoriia [National history], no. 4 (1997): 69; cited in Mason, "Women in the Gulag," 148n8; Applebaum, Gulag, 291-292; Galina Mikhailovna Ivanova, Labor Camp Socialism: The Gulag in the Soviet Totalitarian System, trans. Carol Flath, ed. Donald Raleigh (Armonk, NY: M. E. Sharpe, 2000), 188.

64. Joffe, Back in Time, 1-2 and 237.

65. Adamova-Sliozberg, My Journey, xx-xxi.

66. Memorial, or as it is known today, Memorial International Society, was founded in 1989. Its goal was to work to restore historical truth about the Soviet past, particularly the Stalinist period. One of its first projects was to develop a database of names of victims of political terror during the Soviet period; over time its branches spread throughout the country and its activities broadened to include research, scholarship, and enlisting public support for memorializing victims of Soviet terror. At present, in addition to its overseeing of archives, museums, public memorials, and digital collections, it also monitors human rights abuses throughout the former Soviet Union and is active in defending civil liberties.

67. Ievleva-Pavlenko, "Unedited Life," in Remembering the Darkness, 317-354.

68. Adamova-Sliozberg, My Journey, 122-123.

69. Ibid., 58-60. One chapter ends with a poem devoted to her mother. She also includes a poem she wrote describing her mother sitting high above her, calling out to her while she was sitting alone at the "bottom" of a river. Ibid., 124.

70. Nadezhda also notes that she and her husband were given the "luxury" of being transported together to Kolyma, and even enjoyed for a brief time the right to be in the same camp. No one stopped them from spending nights together, and this is how Lera was conceived. See Joffe, Back in Time, 94 and 109-114.

71. Adamova-Sliozberg, My Journey, 229.

72. Miklashevskaia, Povtorenie proidennogo, 345.

73. Adamova-Sliozberg, My Journey, 230. 
74. Ibid., 37-38, 47, 58, 61, and 230.

75. Joffe, Back in Time, 98.

76. Ibid., 41.

77. Ibid., 121-122.

78. Miklashevskaia, Povtorenie proidennogo, 335. All translations are the author's unless otherwise stated.

79. Ibid., 348, 351-352.

80. Adamova-Sliozberg, My Journey, 62.

81. Ibid., 95-96.

82. Joffe, Back in Time, 114.

83. Ibid., 114-115.

84. Ibid., 130.

85. Adamova-Sliozberg, My Journey, 90-91.

86. Pavlenko, "An Unedited Life," 325, 327, 328, 348.

87. Joffe, Back in Time, 120-123, 137.

88. Ibid, 128.

89. Ibid., 122-124.

90. Ibid., 123-124.

91. Ibid., 180-181.

92. Ibid., 154-155, 198-199.

93. Miklashevskaia, Povtorenie proidennogo, 334-335.

94. Ibid., 371.

95. Ibid., 353-355, 365-366.

96. Joffe, Back in Time, 132-134.

97. Adamova-Sliozberg, My Journey, 136-138; as well as 37-38, 62-65, 114, 117, 139-140, $150-161$.

98. Ibid., 174.

99. Ibid., 179.

100. Ibid., 183-186.

101. For more examples of how difficult reunions could be for returning survivors, see Frierson and Vilensky, Children of the Gulag, 316-321; Shapovalova, "Sestrenki, mamki, damki," 159-160. See also on the difficulties of readjusting to life after the Gulag, Adler, The Gulag Survivor; Nanci Adler, Keeping Faith with the Party: Communist Believers Return from the Gulag (Bloomington: Indiana University Press, 2012); Stephen F. Cohen, The Victims Return: Survivors of the Gulag After Stalin (Exeter, NH: PublishingWorks, 2010).

102. Adamova-Sliozberg, My Journey, 221-233.

103. Veronika Shapovalova discusses Valentina's youth as a factor in her analysis of Valentina's memoir and her behavior in the camps. Shapovalova stresses that she was arrested at an impressionable age, eighteen, and it was easy for her to pick up on the amorality of the camps and interact with as well as adopt the ways of criminal prisoners. See Shapovalova, "Sestrenki, mamki, damki," 156.

104. Ievleva, "Vstrecha s shkol'nikami."

105. Joffe, Back in Time, 172-176.

106. Ibid., 229.

107. Ibid., 234.

108. Helen Halyard, "A Socialist Opponent of Stalinism," Workers Liberty, no. 57 (September 1999): 26, http://archive.workersliberty.org/wlmags/index.html\#by\%20issue (accessed 25 October 2018).

109. See Alexopolous, "Stalin and the Politics of Kinship," 101-106. 
110. Shapovalova, "Sestrenki, mamki, damki," 144, 148; Kuzin, "Zhenshchiny Gulaga."

111. See, e.g., Arsenii Formakov and Emily Johnson, eds., Gulag Letters, Yale-Hoover Series on Authoritarian Regimes (New Haven, CT: Yale University Press, 2017); Oksana Dray-Khmara Asher, Letters from the Gulag: The Life, Letters and Poetry of Michael Dray-Khmara (New York: Robert Speller and Sons, 1983). 